\title{
Baza noclegowa i towarzysząca - wybrane elementy infrastruktury polskich parków narodowych w latach 2005-2015
}

\author{
Selected Elements of the Infrastructure of Polish National Parks from 2005 to 2015
}

\author{
Milena Bera, Aneta Zaremba \\ Wydział Ekonomiczny, Zachodniopomorski Uniwersytet Technologiczny w Szczecinie \\ ORCID: MB https://orcid.org/0000-0002-1997-349X; AZ https://orcid.org/0000-0002-5937-8548• milena.bera@zut.edu.pl \\ Zgłoszono: 21.02.2021; zrecenzowano: 11.04.2021; zaakceptowano do druku: 21.04.2021
}

Streszczenie: Parki narodowe są obszarem bardzo atrakcyjnym turystycznie. Corocznie przybywają tam miliony turystów, a ich liczba ciągle rośnie. Powoduje to wiele problemów w zarządzaniu obszarem chronionym. Stąd też istotne jest zapewnienie odpowiedniej infrastruktury oraz przygotowanie tras turystycznych na tych obszarach tak, aby jak najmniej szkodzić przyrodzie. Celem artykułu jest charakterystyka i ocena zagospodarowania turystycznego i rekreacyjnego parków narodowych w Polsce w latach 2005-2015. Na podstawie zgromadzonych danych empirycznych pochodzących z Głównego Urzędu Statystycznego dokonano porównania wybranych elementów wpływających na zagospodarowanie i przystosowanie danego obszaru parku narodowego do ruchu turystycznego, głównie bazy noclegowej i towarzyszącej. Analiza porównawcza wykazała zróżnicowanie badanych parków w omawianym zakresie. Z przeprowadzonych badań wynika, że największy udział w bazie noclegowej w parkach narodowych miały kempingi i biwaki, z zauważalną tendencją spadkową w każdym analizowanym roku. Liczba ośrodków i domów wczasowych również uległa nieznacznemu zmniejszeniu. Ponadto, w latach 2005-2015 zauważa się tendencję wzrostową w gęstości i długości szlaków, długości nartostrad i schronów przeciwdeszczowych.

Słowa kluczowe: park narodowy, infrastruktura turystyczna, ochrona przyrody

\begin{abstract}
National parks are a very attractive area for tourists. Millions of tourists come there every year, and their number is still growing. This causes many problems in managing the protected area. Therefore, it is important to provide adequate infrastructure and prepare tourist routes in these areas in order to harm nature as little as possible. The aim of the article is to characterize and evaluate the tourist and recreational development of national parks in Poland in the years 20052015. On the basis of the collected empirical data from the Central Statistical Office a comparison was made of selected elements influencing the development and adaptation of a given area of a national park to tourist traffic. A comparative analysis showed the diversity of the studied parks in the discussed scope. The research shows that campsites and bivouacs had the largest share in the accommodation base in national parks, with a noticeable downward trend in each analyzed year. The number of resorts and holiday homes also decreased slightly. On the other hand, between 2005 and 2015 there is an upward trend in the density and length of trails, pistes, and rain shelters.
\end{abstract}

Keywords: national park, tourist infrastructure, nature protection 


\section{Wprowadzenie}

W celu ochrony najcenniejszych walorów przyrody na wyznaczonych obszarach Polski tworzy się m.in. parki narodowe i krajobrazowe, rezerwaty i pomniki przyrody oraz obszary Natura 200o. Objęcie wymienionymi formami ochrony przyrody wprowadza różne ograniczenia dla działalności ludzi (w tym działalności gospodarczej), ale jest także szansą na nowe kierunki rozwoju, w tym turystki przyrodniczej. Obowiązująca w Polsce Ustawa z dnia 16 kwietnia 2004 r. o ochronie przyrody określa park narodowy jako „obszar wyróżniający się szczególnymi wartościami przyrodniczymi, naukowymi, społecznymi, kulturowymi i edukacyjnymi, o powierzchni nie mniejszej niż 1000 ha, na którym ochronie podlega cała przyroda oraz walory krajobrazowe" (Ustawa 2004). Są to tereny z naturalnymi układami ekologicznymi, które powstały na skutek działania przyrody i położenia geograficznego.

Obszary parków narodowych utrzymywane są m.in. ze środków budżetu państwa, Narodowego Funduszu Ochrony Środowiska i Gospodarki Wodnej oraz z własnych finansów (Zbaraszewski 2016, 362-363). Parki uzyskują przychody dzięki sprzedaży własnych wydawnictw, drewna oraz innych produktów uzyskiwanych w ramach ochrony ekosystemów nieleśnych i wodnych: wypasy, siano, ryby itp. (Włodarczyk 2011, 23). Dochód stanowią także bilety wstępu oraz mandaty nakładane osobom łamiącym przepisy.

Parki narodowe mają wyznaczone granice, odpowiedni personel i zarząd. Są udostępnione dla rozwoju nauki, turystyki i rekreacji. Najważniejsze jednak jest zabezpieczenie ekosystemów w taki sposób, aby zachować różnorodność gatunków zwierząt i roślin, cech geomorfologicznych oraz krajobrazu. Prewencja przyrody ożywionej i nieożywionej jest bowiem jednym z celów tworzenia parków narodowych. Kolejnymi są: utrzymanie zasobów, składników przyrody nieożywionej i walorów krajobrazowych oraz odtworzenie zniekształconych siedlisk roślin, zwierząt i grzybów (Broszura informacyjna 2010, 15). W związku z tym na terenie wszystkich parków narodowych obowiązują zasady określone w regulaminach. Parki narodowe są dostępne dla zwiedzających, ale z wyłączeniem obszarów pod ścisłą ochroną. Nie maleje liczba osób spędzająca czas wolny w parkach narodowych, ale nadmierny ruch turystyczny i ingerencja człowieka powodują zniszczenia naturalnych atutów przyrody, stymulując konflikt pomiędzy ekologią a turystyką. I tak, z jednej strony, mamy do czynienia z ciągłym wzrostem popytu turystycznego, a z drugiej strony, powierzchnia terenów do rekreacji jest ograniczona (Opaschowski 1991, 168). Dla środowiska niebezpieczne są m.in. hałas, zanieczyszczenie powietrza i wód czy wycinka lasów. Następstwem jest degradacja środowiska naturalnego, np.: skażenie wody i powietrza, zmniejszenie ilości bądź utrata minerałów w glebie i spadek jej jakości, spustoszenie szaty roślinnej, a także wyginięcie niektórych gatunków zwierząt. Istotne zatem jest posiadanie danych dotyczących ruchu turystycznego, dzięki którym można oszacować wpływ turystów na środowisko przyrodnicze i podjąć odpowiednie kroki, by negatywne oddziaływanie było jak najmniejsze (Fleuer and Hunziker 2007, 192).

Celem niniejszego artykułu jest charakterystyka i ocena zagospodarowania turystycznego i rekreacyjnego parków narodowych w Polsce na przykładzie wybranych parametrów wpływających na zagospodarowanie i przystosowanie danego ich obszaru do ruchu turystycznego. Przestrzenny zakres badań dotyczy parków narodowych na terenie całej Polski. Badanie opiera się na danych empirycznych dotyczących bazy noclegowej oraz bazy towarzyszącej, w postaci gęstości szlaków. Dane empiryczne pozyskano z Głównego Urzędu Statystycznego i dotyczą one czasookresu od 2005 do 2015 roku. Metodologię badań oparto na miarach statystycznych z zakresu analizy struktury i zmian w czasie. Ponadto, w zakresie przetwarzania zgromadzonych danych, wykorzystano metody rozumowania indukcyjnego i dedukcyjnego. 


\section{Charakterystyka parków narodowych w Polsce}

Na terenie całej Polski znajdują się 23 parki narodowe (GUS 2019). Stanowią one swoistą „wizytówkę", prezentując charakterystyczne warunki naturalne konkretnych rejonów kraju (Włodarczyk 2011, 12). W tabeli 1. zestawiono wszystkie parki narodowe w Polsce wraz z ich powierzchnią, datą założenia, położeniem i cechami wyróżniającymi.

Parki narodowe są zróżnicowane pod względem zajmowanej powierzchni, dlatego w 2007 r. usystematyzowano je w pięć grup, w zależności od wielkości terenu. Tabela 2 przedstawia ilość parków narodowych należących do danej grupy (Liszewski 2009,

Tab. 1. Charakterystyka parków narodowych w Polsce

\begin{tabular}{|c|c|c|c|c|c|}
\hline Lp. & $\begin{array}{c}\text { Nazwa parku } \\
\text { narodowego (PN) }\end{array}$ & $\begin{array}{l}\text { Powierzchnia } \\
{\left[\mathrm{km}^{2}\right]}\end{array}$ & Data założenia & $\begin{array}{c}\text { Położenie } \\
\text { w województwach }\end{array}$ & Cechy wyróżniające \\
\hline 1. & Pieniński PN & 23,46 & 1.06 .1932 & małopolskie & $\begin{array}{l}\text { transgraniczny obszar chroniony wraz } \\
\text { z Pieninským národným parkiem }\end{array}$ \\
\hline 2. & Białowieski PN & 105,17 & 11.08 .1932 & podlaskie & $\begin{array}{l}\text { rezerwat biosfery UNESCO, wpisany na } \\
\text { listę światowego dziedzictwa UNESCO, jest } \\
\text { ostatnim naturalnym siedliskiem żubra, leży } \\
\text { na terenach Polski i Białorusi }\end{array}$ \\
\hline 3. & Świętokrzyski PN & 76,26 & 1.05 .1950 & świętokrzyskie & $\begin{array}{l}\text { gołoborza w Górach Świętokrzyskich } \\
\text { (najstarsze góry w Polsce) }\end{array}$ \\
\hline 4. & Babiogórski PN & 33,90 & 30.10 .1954 & małopolskie & rezerwat biosfery UNESCO \\
\hline 5. & Tatrzański PN & 211,87 & 1.01 .1955 & małopolskie & $\begin{array}{l}\text { występowanie świstaka tatrzańskiego } \\
\text { (podgatunku endemicznego) }\end{array}$ \\
\hline 6. & Ojcowski PN & 21,46 & 14.01 .1956 & małopolskie & $\begin{array}{l}\text { obszar wapienny, występuje m.in. Maczuga } \\
\text { Herkulesa }\end{array}$ \\
\hline 7. & Wielkopolski PN & 75,83 & 16.04 .1957 & wielkopolskie & $\begin{array}{l}\text { Trasa Kórnicka, Pierścień Rowerowy dookoła } \\
\text { Poznania }\end{array}$ \\
\hline 8. & Karkonoski PN & 55,80 & 16.01 .1959 & dolnośląskie & $\begin{array}{l}\text { wraz z Krkonošským národním parkiem } \\
\text { tworzy rezerwat biosfery UNESCO }\end{array}$ \\
\hline 9. & Kampinoski PN & 385,48 & 16.01 .1959 & mazowieckie & $\begin{array}{l}\text { rezerwat biosfery UNESCO, obszar Natura } \\
2000\end{array}$ \\
\hline 10. & Woliński PN & 150,79 & 15.03 .1960 & $\begin{array}{l}\text { zachodnio- } \\
\text { pomorskie }\end{array}$ & jezioro Turkusowe - dawna kopalnia kredy \\
\hline 11. & Słowiński PN & 215,72 & 1.01 .1967 & pomorskie & wydmy ruchome \\
\hline 12. & Bieszczadzki PN & 291,96 & 4.08 .1973 & podkarpackie & $\begin{array}{l}\text { rezerwat biosfery UNESCO, dyplom Europy, } \\
\text { obszar Natura } 2000\end{array}$ \\
\hline 13. & Roztoczański PN & 84,82 & 1.05 .1974 & lubelskie & rezerwatowa hodowla konika polskiego \\
\hline 14. & Gorczański PN & 70,30 & 8.08 .1980 & małopolskie & polany gorczańskie \\
\hline 15. & Wigierski PN & 150,79 & 1.01 .1989 & podlaskie & $\begin{array}{l}\text { szczególna ochrona storczykowatych ( } 22 \\
\text { gatunki), jezioro Wigry - najcenniejszy } \\
\text { akwen świata }\end{array}$ \\
\hline 16. & Drawieński PN & 113,42 & 1.05 .1990 & $\begin{array}{l}\text { lubuskie, } \\
\text { wielkopolskie } \\
\text { i zachodnio- } \\
\text { pomorskie }\end{array}$ & $\begin{array}{l}\text { jezioro Czarne - jedno z najczystszych } \\
\text { w Polsce }\end{array}$ \\
\hline & Poleski PN & 97,62 & 01.05 .1990 & lubelskie & $\begin{array}{l}\text { obszary chronione konwencją ramsarską, } \\
\text { rezerwat biosfery UNESCO }\end{array}$ \\
\hline 18. & Biebrzański PN & 592,23 & 09.09 .1993 & podlaskie & $\begin{array}{l}\text { wodno-błotne obszary chronione konwencją } \\
\text { ramsarską }\end{array}$ \\
\hline 19. & PN Gór Stołowych & 63,40 & 16.09 .1993 & dolnośląskie & $\begin{array}{l}\text { występowanie jedynych w Polsce gór } \\
\text { płytowych }\end{array}$ \\
\hline
\end{tabular}




\begin{tabular}{llclll}
\hline Lp. & $\begin{array}{c}\text { Nazwa parku } \\
\text { narodowego (PN) }\end{array}$ & $\begin{array}{c}\text { Powierzchnia } \\
{\left[\mathrm{km}^{2}\right]}\end{array}$ & Data założenia & $\begin{array}{c}\text { Położenie } \\
\text { w województwach }\end{array}$ & Cechy wyróżniające \\
\hline 20. & Magurski PN & 194,39 & 01.01 .1995 & $\begin{array}{l}\text { małopolskie } \\
\text { i podkarpackie }\end{array}$ & pozostałości po kulturze kemków \\
\hline 21. & $\begin{array}{l}\text { PN „Bory } \\
\text { Tucholskie" }\end{array}$ & 46,13 & 01.07 .1996 & pomorskie & rezerwat biosfery UNESCO \\
\hline 22. & Narwiański PN & 68,10 & 01.07 .1996 & podlaskie & $\begin{array}{l}\text { od 2010 r. ostoja ptaków IBA (Important Bird } \\
\text { Areas) }\end{array}$ \\
\hline 23. PN "Ujście Warty" & 80,74 & 01.07 .2001 & lubuskie & $\begin{array}{l}\text { obszar Natura 2000, największe zimowisko } \\
\text { łabędzia krzykliwego w Polsce }\end{array}$ \\
\hline
\end{tabular}

Źródło: Opracowanie własne (dane z 1.10.2017).

Tab. 2. Grupy parków narodowych w Polsce w zależności od powierzchni $\left(\mathrm{km}^{2}\right)$

\begin{tabular}{lc}
\hline Wielkość powierzchni $\left[\mathrm{km}^{2}\right]$ & Liczba parków \\
\hline poniżej 50,0 & 4 \\
\hline $50,1-100,0$ & 9 \\
\hline $100,1-150,0$ & 4 \\
\hline $151,0-250,0$ & 3 \\
\hline powyżej 250,1 & 3 \\
\hline
\end{tabular}

Źródło: Liszewski 2009, s. 188.

188), przy tym najmniejszy pod względem powierzchni jest Ojcowski, największy zaś Biebrzański Park Narodowy.

Parki narodowe w Polsce znajdują się na różnych pasach rzeźby terenu: wyżynach, pojezierzach, na terenach górzystych, nizinnych i nadmorskich (Włodarczyk 2011, 12). Ich rozmieszczenie przedstawia ryc. 1.

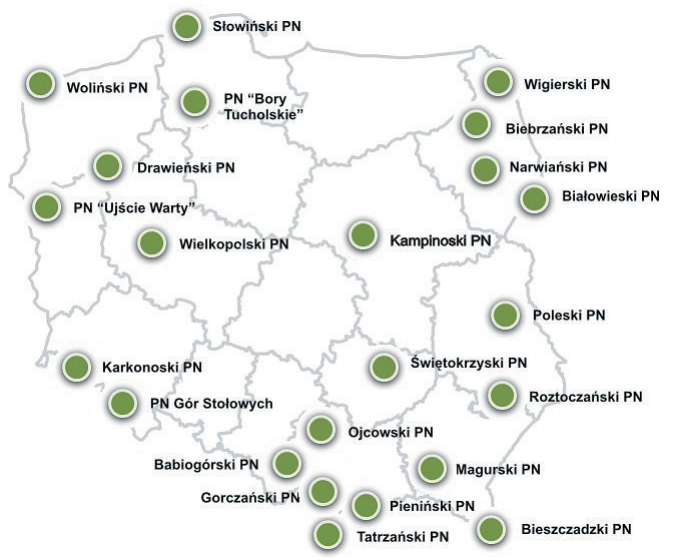

Ryc. 1. Rozmieszczenie parków narodowych w Polsce

Źródło: Ekoportal 2018.
Dzięki różnemu ukształtowaniu powierzchni kraju tereny parków są urozmaicone i można wyodrębnić pięć typów parków narodowych w zależności od ich położenia i pejzażu (Kruczek 2011, 35). Są to:

- górskie parki narodowe, np.: Tatrzański i Bieszczadzki,

- nadmorskie parki narodowe, np.: Woliński,

- wyżynne parki narodowe, m.in.: Ojcowski i Roztoczański,

- pojezierne parki narodowe, np.: Wielkopolski, Ujścia Warty,

- niżowe parki narodowe, np.: Kampinoski, Biebrzański.

Wszystkie parki narodowe w Polsce mają nietuzinkowe atrybuty widokowe, przyrodnicze i wypoczynkowe, w związku z tym każdy z nich ma swoją określoną atrakcyjność turystyczną i krajoznawczą. Na ich terenach prowadzone są liczne badania naukowe, dlatego też są to niezwykle ważne miejsca dla rozwoju dydaktyki, kultury i środowiska.

\section{Uwarunkowania rozwoju turystyki w polskich parkach narodowych}

Parki narodowe spełniają wiele funkcji. Priorytetem jest ochrona terenów całkowicie naturalnych lub w niewielkim stopniu zmienionych przez człowieka. Dla mało liczebnych populacji oraz rzadkich gatunków roślin i zwierząt obszar parku jest często jedyną szansą na przeżycie. Dla turystów, którzy odwiedzają parki narodowe, są one natomiast miejscem odpoczynku i kontaktu $\mathrm{z}$ naturą. 
Rozwojowi rekreacji w parkach narodowych służą wszelkie szlaki turystyczne, wyciągi, miejsca postojowe dla pojazdów czy schrony przeciwdeszczowe. Wszystko to jest konieczne, aby na terenach parków zapewnić zwiedzającym bezpieczeństwo, ma to jednak pejoratywny wpływ na naturę. Bezdyskusyjnie bazy i atrakcje turystyczne oraz udogodnienia dla zwiedzających funkcjonują dzięki pracownikom parków oraz mieszkańcom okolicznych miejscowości. Turystyka, jako jedna z gałęzi gospodarki, na obszarach objętych ochroną przyczynia się także do rozwoju ekonomicznego danego regionu.

Ruch turystyczny w parkach narodowych jest ograniczony. Jest to niezbędne do tego, aby nie powodował szkód i zaburzeń funkcjonowania ekosystemów. Tereny parków podlegają ochronie ścisłej lub częściowej (Wyrzykowski i in. 2008, 103). Ze względu na stopień intensywności użytkowania turystycznego parki narodowe w Polsce można podzielić na (Miazek 2020, 84):

- parki o dużej liczbie turystów (powyżej $1 \mathrm{mln}$ ): Kampinoski, Karkonoski, Wielkopolski, Woliński, Tatrzański;

- parki o średniej liczbie turystów (od 100 tys. do $1 \mathrm{mln}$ ): Białowieski, Bieszczadzki, Gór Stołowych, Ojcowski, Pieniński, Roztoczański, Słowiński, Świętokrzyski, Wigierski;

- parki o małej liczbie turystów (do 100 tys.): Babiogórski, Biebrzański, Bory Tucholskie, Drawieński, Gorczański, Magurski, Narwiański, Poleski, Ujście Warty.

Zainteresowanie parkami - Tatrzańskim, Karkonoskim i Wolińskim - może być związane z ich urokliwym położeniem geograficznym. Karpaty i Sudety oraz Morze Bałtyckie są bowiem od lat znaczącymi punktami turystycznymi w Polsce. Natomiast parki - Wielkopolski w okolicy Poznania, Ojcowski niedaleko Krakowa oraz Kampinoski blisko Warszawy - mogą być ciekawym miejscem, w którym można odpocząć od zgiełku miasta i obcować $\mathrm{z}$ naturą.
Parki narodowe są także ważnym miejscem historycznym i pomnikiem pamięci narodowej, dlatego turystykę i rekreację należy dostosować tak, aby ingerencja człowieka w środowisko naturalne była jak najmniejsza, a przeprowadzanie badań naukowych i ochronnych nadal możliwe.

Większość interesujących obiektów jest dostosowana do turystów. Zagospodarowanie turystyczne polega na przystosowaniu danego terenu do ruchu turystycznego. Istotne są tu baza noclegowa i gastronomiczna, dostępność komunikacyjna (Wyrzykowski i in. 2008, 103) oraz baza towarzysząca (Kowalczyk 2002, 112). Podział urządzeń zagospodarowania turystycznego jest następujący:

- turystyczne (służą do obsługi odwiedzających),

- paraturystyczne (przeznaczone do innych potrzeb społeczno-gospodarczych, korzystają z nich nie tylko turyści).

Baza noclegowa zapewnia podstawowe potrzeby bytowe człowieka. Wyróżnia się tutaj między innymi takie obiekty, jak: hotele, motele, pensjonaty, schroniska, hotele, ośrodki wczasowe i szkoleniowo-wypoczynkowe, pola biwakowe, kwatery agroturystyczne (GUS 2018), czyli miejsca, które za opłatą udostępniają nocleg podróżującym według obowiązujących zasad i przepisów (Ustawa 1997).

W aspekcie rozwoju turystyki ważne są także szlaki turystyczne (rowerowe i piesze), kolejki linowe, wyciągi narciarskie, przystanki, porty, lotniska. Szlaki turystyczne są tworzone w celach ekologicznych i turystycznych. Są wyznaczone w taki sposób, aby podróżujący byli bezpieczni, nie zbaczali z trasy i nie niszczyli środowiska naturalnego, a jednocześnie mogli podziwiać widoki i korzystać z dostępnych walorów przyrodniczych. Szlaki turystyczne są oznakowane specjalnymi symbolami i tablicami, dzięki którym zwiedzający mogą się poruszać (Pttk.pl 2018). Oznakowaniem szlaków pieszych zajmuje się Polskie Towarzystwo Turystyczno-Krajoznawcze przy udziale 
władz samorządowych, krajowych i regionalnych oraz lokalnych organizacji turystycznych (Wyrzykowski i in. 2008, 223). Ruch turystyczny w parkach narodowych jest dozwolony jedynie na szlakach.

Dbałość o potrzeby odwiedzających parki narodowe jest m.in. podstawą tworzenia oferty turystycznej. W tym celu niezbędny jest monitoring turystyczny (Matczak 2002 17; Wolf et al. 2012, 17).

Atrakcyjność turystyczna danego obszaru, miejscowości czy szlaku rośnie także wraz z możliwością dojazdu środkami komunikacji oraz wystarczającą liczbą miejsc parkingowych, pól biwakowych, szlaków turystycznych i wież widokowych (Wyrzykowski i in. 2008, 16-17), dostępnością ośrodków przyjmujących turystów i służących im do rekreacji oraz punktów gastronomicznych (Kowalczyk 2002, 111).

\section{Zagospodarowanie turystyczne i rekreacyjne parków narodowych w Polsce w latach 2005-2015}

W celu zidentyfikowania zmian, jakie zaszły w zagospodarowaniu turystycznym w parkach narodowych w latach 2005-2015, przeanalizowano dane dotyczące bazy noclegowej i bazy towarzyszącej w postaci gęstości szlaków.

Rycina 2. przedstawia zmiany, jakie dokonały się $w$ analizowanym okresie w liczbie schronisk, domów wczasowych i kempingów funkcjonujących w parkach narodowych. Z wykresu wynika, iż największy udział w bazie noclegowej w każdym z analizowanych okresów miały kempingi i biwaki. Tego typu obiekty zdecydowanie są dużym ułatwieniem w pieszych wędrówkach w czasie niepogody, zwłaszcza na obszarach nizinnych. Do zalet zakwaterowania na polu biwakowym czy kempingowym można zaliczyć przede wszystkim niższą cenę wynajmu aniżeli w domu wczasowym, stały dostęp świeżego powietrza oraz poczucie niezależności od rezerwacji. Niemniej odnotowano ich spadek: z 65 kempingów i biwaków w roku 2005 do 31 w roku 2015. Liczba schronisk w danym okresie utrzymywała

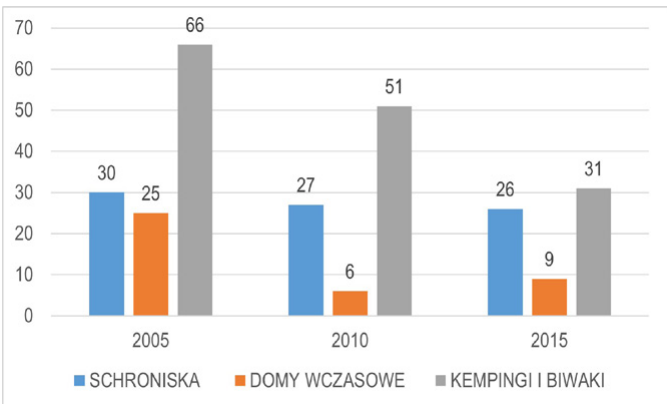

Ryc. 2. Liczba (\%) schronisk, domów wczasowych i kempingów funkcjonujących na terenie parków narodowych w latach 2005-2015

Źródło: Opracowanie własne na podstawie danych Głównego Urzędu Statystycznego.

się na zbliżonym poziomie. W 2005 r. funkcjonowało 30 schronisk, a w 2015 r. liczba ta spadła do 26. Największy spadek odnotowano w przypadku domów wczasowych: Z 25 w 2005 r. do 9 w 2015 r.

Gęstość szlaków dla danego parku narodowego jest to iloraz długości szlaków wyrażonej w km i całkowitej powierzchni parków $\mathrm{w} \mathrm{km}^{2}$. W tabeli 3. przedstawiono dane dotyczące gęstości szlaków w parkach narodowych w latach $2005^{-2015}$.

Jak wynika z tabeli 3., największą gęstość szlaków turystycznych w 2005 r. odnotowano w dwóch parkach narodowych: Wielkopolskim $\left(2,84 \mathrm{~km} / \mathrm{km}^{2}\right)$ i "Gór Stołowych" $\left(2,65 \mathrm{~km} / \mathrm{km}^{2}\right)$, najmniejszą natomiast w parku narodowym "Ujście Warty” $\left(0,16 \mathrm{~km} / \mathrm{km}^{2}\right)$, Poleskim $\left(0,39 \mathrm{~km} / \mathrm{km}^{2}\right)$ i Białowieskim $\left(0,37 \mathrm{~km} / \mathrm{km}^{2}\right)$.

Między 2005 a 2010 r. zanotowano niewielkie różnice w gęstości szlaków w parkach narodowych. Spadek gęstości szlaków zauważa się w parkach narodowych: „Bory Tucholskie" (o o,72 km/ $\mathrm{km}^{2}$ ), Roztoczańskim (o o,35 km/ $\mathrm{km}^{2}$ ) i Świętokrzyskim (o o,05 $\mathrm{km} / \mathrm{km}^{2}$ ). Na obszarze parku narodowego „Ujście Warty” odnotowano wysoki wzrost gęstości szlaków, który wyniósł 1,36km/ $\mathrm{km}^{2}$. Przyczyną tego może być fakt, iż park ten jest położony niedaleko granicy polsko-niemieckiej, a wydłużenie szlaków pieszych jest formą zachęcenia obcokrajowców do odwiedzenia parku. W 2015 r. nastąpiło 
Tab. 3. Gęstość szlaków w parkach narodowych w latach $2005^{-2015}\left(\mathrm{~km} / \mathrm{km}^{2}\right)$

\begin{tabular}{lccc}
\hline Park Narodowy & \multicolumn{3}{c}{ Gęstość szlaków } \\
\cline { 2 - 4 } & 2005 r. & 2010 r. & 2015 r. \\
\hline Babiogórski & 1,56 & 1,56 & 1,45 \\
\hline Białowieski & 0,37 & 0,42 & 0,42 \\
\hline Biebrzański & 0,78 & 0,78 & 0,84 \\
\hline Bieszczadzki & 0,93 & 0,48 & 1,59 \\
\hline Bory Tucholskie & 2,35 & 1,63 & 2,02 \\
\hline Drawieński & 0,78 & 1,50 & 2,13 \\
\hline Gorczański & 1,50 & 2,21 & 2,40 \\
\hline Gór Stołowych & 2,65 & 2,59 & 1,72 \\
\hline Kampinoski & 0,93 & 1,45 & 1,43 \\
\hline Karkonoski & 2,11 & 2,11 & 2,17 \\
\hline Magurski & 0,44 & 0,50 & 0,48 \\
\hline Narwiański & 0,61 & 0,75 & 0,81 \\
\hline Ojcowski & 1,07 & 1,85 & 1,74 \\
\hline Pieniński & 1,48 & 1,49 & 1,49 \\
\hline Poleski & 0,36 & 1,43 & 1,17 \\
\hline Roztoczański & 0,71 & 0,36 & 0,35 \\
\hline Słowiński & 0,67 & 0,67 & 0,77 \\
\hline Świętokrzyski & 0,54 & 0,49 & 0,54 \\
\hline Tatrzański & 1,30 & 1,30 & 1,30 \\
\hline Ujście Warty & 0,16 & 1,52 & 0,21 \\
\hline Wielkopolski & 2,84 & 2,84 & 2,84 \\
\hline Wigierski & 1,53 & 1,64 & 1,81 \\
\hline Woliński & 0,43 & 0,458 & 0,46 \\
\hline Ogółem & 26,1 & 30,0 & 30,1 \\
\hline Zró & & \\
\hline
\end{tabular}

Źródło: Opracowanie własne na podstawie danych Departamentu Badań Społecznych, Wydział Statystyki i Turystyki, Sportu, Kultury i Dziedzictwa Narodowego, Główny Urząd Statystyczny, 2018.

zwiększenie gęstości szlaków w stosunku do 2010 r. Największy wzrost odnotowano w Bieszczadzkim Parku Narodowym, gdzie różnica sięga $1,11 \mathrm{~km} / \mathrm{km}^{2}$ oraz w Drawieńskim, gdzie różnica wyniosła $0,63 \mathrm{~km} / \mathrm{km}^{2}$.

Analizując gęstość szlaków w parkach narodowych w latach 2000-2015, należy zauważyć, że w bieszczadzkim, drawieńskim i gorczańskim parku narodowym nastąpił szczególnie zauważalny wzrost gęstości istniejących szlaków, kolejno odpowiednio o: o,88; 1,45 i $1,35 \mathrm{~km} / \mathrm{km}^{2}$.

Ogólnie wiadomo, że miarą atrakcyjności parków narodowych jest baza towarzysząca, na którą oprócz szlaków turystycznych składają się również nartostrady, kolejki linowe, wyciągi narciarskie. Na podstawie analiz statystycznych Głównego Urzędu Statystycznego (Analizy statystyczne 2016) najdłuższe nartostrady w 2015 r. istniały w tatrzańskim i karkonoskim parku narodowym. Ma to związek ze sprzyjającym ukształtowaniem terenu oraz intensywną pracą człowieka nad poprawą warunków dla turystów, a także dobrze rozwiniętym zapleczem i infrastrukturą uzupełniającą, będącą dla odwiedzających dodatkową atrakcją i ułatwieniem podróżowania. Kolejki linowe posiadały dwa parki narodowe, tj. Karkonoski i Tatrzański. Ogółem ich liczba w 2015 r. wynosiła 11 i występują one głównie na terenach górskich. W badanych latach zauważa się ich spadek: z 20 w roku 2005 (Analizy statystyczne 2006) do 13 w roku 2015 (Analizy statystyczne 2006), co może wiązać się z wysokimi kosztami utrzymania i obsługi, dużym wyeksploatowaniem i koniecznymi pracami modernizacyjnymi.

\section{Podsumowanie}

W wyniku analizy danych empirycznych dotyczących zagospodarowania turystycznego i rekreacyjnego polskich parków narodowych w latach 2005-2015 należy stwierdzić, że dynamika liczby miejsc noclegowych wykazuje tendencję malejącą. Największy udział w bazie noclegowej miały pola kempingowe i biwakowe z zauważalną tendencją spadkową w każdym analizowanym roku. W roku 2005 i 2010 najwięcej pól kempingowych i biwakowych istniało w Wigierskim Parku Narodowym, a najmniej w Babiogórskim, Świętokrzyskim i Wielkopolskim. Z punktu widzenia turystów, którzy chcieliby skorzystać z pobytu długoterminowego w danym parku, może być to zjawisko negatywne. Zaistniała sytuacja powoduje, że często zmuszeni są oni poszukiwać miejsc noclegowych w wydzielonych obszarach ochronnych wokół parku narodowego.

Badania jednoznacznie wykazały sukcesywny wzrost zagęszczenia szlaków turystycznych w parkach narodowych. Największy odnotowano w najmłodszym Parku Narodowym „Ujście Warty” w 2010 r. 
i wynosił $1,52 \mathrm{~km} / \mathrm{km}^{2}$. Rosnąca gęstość szlaków wynikała z coraz większej potrzeby powiększania obszarów dostępnych dla turystów zainteresowanych szlakami. Poza tym należy podkreślić, że szlaki turystyczne spełniają ważną rolę w rozwijaniu turystyki na danym obszarze, jego promocji i kształtowaniu turystyki przyjaznej środowisku naturalnemu. Mając na uwadze powyższy fakt, należy stwierdzić, iż jako część zagospodarowania turystycznego szlaki przede wszystkim mają na celu ochronę, przystosowanie oraz udostępnianie turystom walorów turystycznych, zapewniając im dostęp do miejsc będących.

Celem utworzenia każdego parku narodowego jest zachowanie różnorodności biologicznej, zasobów, tworów i składników przyrody nieożywionej, a także walorów krajobrazowych. Różne formy turystyki przyczyniają się do znacznego wpływu na środowisko, często prowadząc do degradacji walorów turystycznych. Coraz bardziej istotne znaczenie ma zapewnienie odpowiedniej infrastruktury oraz przygotowanie tras turystycznych w parkach narodowych tak, aby jak najmniej szkodzić przyrodzie i głównie tam kierować ruch turystyczny.

\section{Bibliografia}

Analizy statystyczne. 2006. Ochrona środowiska. Warszawa: Główny Urząd Statystyczny.

Analizy statystyczne. 2016. Ochrona środowiska. Warszawa: Główny Urząd Statystyczny.

Broszura informacyjna. 2010. Monitoring, zagrożenia i zadania ochronne. Chyrzno: Park Narodowy „Ujście Warty”.

DBS (Departament Badań Społecznych Wydział Statystyki i Turystyki, Sportu, Kultury i Dziedzictwa Narodowego). 2018. Baza noclegowa wedtug stanu w dniu 31 lipca 2018 r. i jej wykorzystanie w I pótroczu 2018 roku. Warszawa: Główny Urząd Statystyczny.

Ekoportal 2018 - Ekoportal.gov.pl. 2018. Parki narodowe w Polsce. Dostęp 20.09.2018. http:// www.ekoportal.gov.pl/informacja-o-srodowisku/ polskie-parki-narodowe.

Fleuer, Benjamin, and Marcel Hunzikier. 2007. "Reaction activities in protected areas. Bringing the gap between the attitudes and behavior of snowshoe walkers." Forest Snow and Landscape Research 81(1/2): 192

GUS (Główny Urząd Statystyczny). 2018. www.stat. gov.pl.

GUS (Główny Urząd Statystyczny). 2019. www.stat. gov.pl.

Kowalczyk, Andrzej. 2002. Geografia Turyzmu. Warszawa: Wydawnictwo Naukowe PWN.

Kruczek, Zofia. 2011. Polska. Geografia atrakcji turystycznych. Kraków: Proksenia.

Liszewski, Stanisław. 2009. Przestrzeń turystyczna parków narodowych $w$ Polsce. Łódź: Uniwersytet Łódzki.

Matczak, Andrzej. 2002. „Metodyka badań ruchu turystycznego na obszarach chronionych." W: Użytkowanie turystyczne parków narodowych. Ruch turystyczny - zagospodarowanie - konflikty-zagrożenia, red. Józef Partyka, 17-22. Ojców: Ojcowski Park Narodowy.

Miazek, Piotr. 2020. „Przyczyny zróżnicowania ruchu turystycznego w polskich parkach narodowych." Tourism 30(1): 73-86.

Opaschowski, Horst. 1991. Ökologie von Freizeit und Tourismus. Opladen: Leske + Budrich.

Pttk.pl. 2018. Polskie Towarzystwo Turystyczno-Krajoznawcze. Dostęp 11.12.2018. https://www.pttk. pl/szlaki.html\#.X9dBsNJKjZ4.

Ustawa 1997 - Ustawa z dnia 29 sierpnia 1997 r. o Usługach turystycznych (tj. Dz.U. 1997 nr 133 poz. 884 ).

Ustawa 2004 - Ustawa z dnia 16 kwietnia 2004 r. o Ochronie przyrody (tj. Dz.U. 2004 nr 92 poz. 880.).

Włodarczyk, Joanna. 2011. Parki Narodowe Polski. Warszawa: Arti.

Wolf, Isabelle D., Gerald Hagenloh, and David B. Croft. 2012. "Visitor Monitoring along roads and Hiking Trials: How to Determine Usage Levels in Tourist Sites." Tourism Management 33(1): 16-28.

Wyrzykowski, Jerzy, Bogdan Mikułowski, i Teofil Lijewski. 2008. Geografia turystyki Polski. Warszawa: Polskie Wydawnictwo Ekonomiczne.

Zbaraszewski, Wojciech. 2016. „Finansowanie polskich parków narodowych." Ekonomiczne Problemy Ustug 125: 359-358. 